\title{
Vitamina D: Implicații multiple, noi perspective
}

\author{
Laura Florescu', Laura Mihaela Trandafir², Dana Elena Mîndru', \\ Oana-Raluca Temneanu ${ }^{1}$ \\ ${ }^{1}$ Disciplina Puericultură, Departamentul Medicina Mamei şi Copilului, Universitatea de Medicină şi \\ Farmacie „Gr. T. Popa“, Iaşi, România \\ ${ }^{2}$ Disciplina Pediatrie, Departamentul Medicina Mamei şi Copilului, Universitatea de Medicină şi \\ Farmacie „Gr. T. Popa“, Iaşi, România
}

\begin{abstract}
REZUMAT
Deficitul de vitamină D reprezintă o problemă globală de sănătate publică, la toate grupele de vârstă, provocată în principal de expunerea insuficientă la lumina soarelui, diete necorespunzătoare, absorbție şi utilizare ineficiente, cerințe crescute sau pierderi mai mari. Cunoscând implicațiile vitaminei D în organism şi perioadele sensibile de creştere şi dezvoltare, este important să se efectueze determinări biologice, pentru o profilaxie adecvată şi pentru a interveni prompt când apar modificări. Grupele de vârstă la care se recomandă administrarea vitaminei D sunt sugarii (indiferent dacă sunt alimentați natural, cu formulă sau alimentație complementară) şi adolescenţii. În afară de rolul binecunoscut al vitaminei D în metabolismul fosfo-calcic, se discută din ce în ce mai mult de implicarea vitaminei $D$ în patogenia bolilor non-musculo-scheletice.
\end{abstract}

Cuvinte cheie: vitamină D, colecalciferol, deficit de vitamina D, metabolism fosfo-calcic, rahitism carenţial

Rahitismul carențial, descris în literatură încă din secolul al XVII-lea, a fost asociat cu deficitul de vitamina D mulți ani mai târziu, odată cu înțelegerea metabolismului vitaminei $\mathrm{D}$ şi a mecanismului său de acțiune în organele țintă. În perioada 1920-1940, vitamina D, cunoscută inițial ca vitamina soarelui, a fost clasificată mai degrabă ca vitamină decât ca un hormon steroid. Aportul exogen de vitamine trebuie să fie continuu din dietă, deoarece organismul nu le poate sintetiza.

$\mathrm{Cu}$ toate acestea, s-a dovedit că, prin expunerea la soare, are loc producerea fotochimică a vitaminei $\mathrm{D}$, ceea ce demonstrează că aceasta devine o adevărată vitamină doar în absența expunerii regulate la lumina soarelui sau la lumina ultravioletă. Perioada 1650-1963 a reprezentat o etapă importantă în determinarea structurilor chimice ale vitaminei $\mathrm{D}$, iar rolul în ştiințele biologice, clinice sau nutriționale a fost recunoscut mai târziu (1).

Contrar denumirii sale, vitamina D este de fapt un hormon steroid, cunoscut de mult pentru rolul său important în reglarea nivelului de calciu şi fosfor în organism şi în mineralizarea oaselor. Mai recent, a devenit clar faptul că receptorii pentru vitamina D sunt prezenți într-o mare varietate de celule şi că acest hormon are efecte biologice care depăşesc cu mult doar controlul metabolismului fosfo-calcic.

Se cunoaşte faptul că vitamina $D$ este o vitamină liposolubilă, prezentă în mod natural în foarte puține alimente, adăugată în altele şi disponibilă ca supliment alimentar; există în două forme - D2 (ergocalciferol), obținut din drojdie şi plante, şi D3 (colecalciferol), obținut din dietă prin ingestia de produse care conțin vitamina D (peşte gras şi ouă), lapte fortificat cu vitamina D sau margarină şi/sau utilizarea multivitaminelor $(2,3)$.

Vitamina D este, de asemenea, un produs endogen produs sub acțiunea razelor ultraviolete la nivelul pielii. Termenul de vitamina $\mathrm{D}$ este un termen imprecis referitor la unul sau mai mulți membri ai unui grup de molecule de steroizi. Vitamina D obținută în urma expunerii la soare, din alimente şi suplimente este inactivă din punct de vedere biologic. Pentru a deveni biologic activă, vitamina D trebuie 
supusă reacțiilor de hidroxilare, care în organismul uman au loc în două etape:

- Prima în ficat: colecalciferolul este hidroxilat la 25-hidroxi $(\mathrm{OH})$-colecalciferol cu ajutorul enzimei 25-hidroxilază;

- A doua în rinichi: 25-OH-colecalciferolul sub acțiunea alfa1-hidroxilazei se transformă în 1,25-dihidroxi-colecalciferol, forma biologic activă.

Ulterior, este transportată în sânge legată de proteinele carrier (vitamin D-binding protein) către organele țintă, pentru a-şi exercita multiplele roluri în organism (4).

\section{DEFICITUL DE VITAMINA D}

Deficitul de vitamina D reprezintă o problemă globală de sănătate publică, întâlnită la toate grupele de vârstă, provocată în principal de expunerea insuficientă la lumina soarelui, diete necorespunzătoare, absorbție şi utilizare ineficiente, cerințe crescute sau pierderi mai mari. În prezent, deficitul de vitamina $\mathrm{D}$ este mult mai frecvent decât se credea inițial, în special în rândul sugarilor, adolescenților, femeilor şi al vârstnicilor, dar pentru multe țări nu există date raportate, astfel încât prevalența reală nu poate fi raportată (5-7).

O multitudine de factori şi situații contribuie la apariția deficitului de vitamina D. Temerile legate de dezvoltarea unei neoplazii, credințele culturale pot duce la evitarea expunerii la lumina solară, în timp ce hiperpigmentarea pielii şi ineficiența soarelui în timpul anotimpului rece pot contribui la o sinteză redusă de vitamina D la nivel cutanat. Dietele strict vegetariene sau vegane, incluzând lapte vegetal nefortifiat, alimente sărace în vitamina $\mathrm{D}$, contribuie, de asemenea, la apariția deficitului de vitamina D. O categorie aparte este reprezentată de deficitul congenital de vitamina D la sugar, cel mai frecvent secundar deficitului sever la gravidă, din cauza fie aportului deficitar, a expunerii insuficiente la soare, a intervalului mic dintre sarcini sau a domiciliului în zonele nordice, neînsorite (8).

Alte cauze de deficit de vitamina $\mathrm{D}$ sunt bolile hepatice şi renale cronice, care reduc transformarea în formele active, pierderile crescute de vitamina $\mathrm{D}$, deficitul de absorbție la nivel intestinal (fibroza chistică, boala celiacă, sindrom de intestin scurt), consumul cronic al anumitor medicamente (anticonvulsivante, imunosupresoare, chimioterapice, antituberculoase, antiacide, corticosteroizi, anticoagulante), utilizarea excesivă a produselor cu factor de protecție, stresul $(9,10)$.

\section{RECOMANDĂRI ACTUALE PRIVIND PROFILAXIA DEFICITULUI DE VITAMINA D}

Academia Americană de Pediatrie (2008) recomandă suplimentarea cu vitamina D la toți sugarii, doza fiind de $400 \mathrm{UI} / \mathrm{zi}$. În cazul copiilor şi adolescenților, doza recomandată este aceeaşi, 400 UI/zi, în complex de vitamine sau produs unic cu vitamina D (11). Pentru Europa, Comitetul ESPGHAN (European Society for Paediatric Gastroenterology, Hepatology and Nutrition) pentru Nutriție recomandă suplimentarea orală zilnică cu 400 UI vitamină D pentru toți copiii în primul an de viață. În conformitate cu Autoritatea Europeană pentru Siguranța Alimentară, limita superioară este stabilită la $1.000 \mathrm{UI} / z i$ pentru sugari, $2.000 \mathrm{UI} / z i$ pentru copii cu vârste cuprinse între 1 şi 10 ani şi 4.000 UI/zi pentru copii şi adolescenți cu vârsta cuprinsă între 11 şi 17 ani. Pentru grupurile de risc, suplimentarea orală cu vitamina D trebuie luată în considerare după vârsta de 1 an (12).

Dietele vegetariene, din cauza consumului restrictiv şi neechilibrat de principii nutritive, pot conduce la tulburări de creştere şi carențe în micro şi macronutrienți, de aceea se recomandă suplimentarea cu vitamina D (13). Suplimentarea cu vitamina D pentru sugarii alăptaţi exclusiv de către mamele vegetariene este necesară numai în cazul expunerii limitate la lumina soarelui, similar cu sugarii născuți de mame non-vegetariene. Se consideră că, în cazul copiiilor lacto-şi lacto-ovo-vegetarieni, aceştia trebuie să consume lapte de vacă fortificat cu vitamina D în cantitate suficientă, de aceea suplimentarea cu vitamina $\mathrm{D}$ este necesară doar copiilor vegani cu expunere inadecvată la lumina soarelui (14).

O categorie aparte o reprezintă majoritatea sugarilor prematuri $(98,9 \%)$, care au avut deficit de vitamina $\mathrm{D}$, iar la jumătate dintre aceştia deficitul a fost sever. Riscul de deficit de vitamina D nu s-a corelat cu vârsta gestațională mică (15).

\section{VALORILE DE REFERINŢĂ PENTRU CONCENTRATIA SERICĂ A VITAMINEI D}

Concentrația serică este cel mai bun indicator al statusului vitaminei D. Aceasta reflectă vitamina D produsă cutanat şi cea obținută din alimente şi suplimente.

Valorile de referință pentru concentrațiile plasmatice ale 25-hidroxivitaminei D sunt: 
- Deficit $<20 \mathrm{ng} / \mathrm{ml}(<50 \mathrm{nmol} / \mathrm{l})$

- Nivel insuficient: $20-30 \mathrm{ng} / \mathrm{ml}(50-75 \mathrm{nmol} / \mathrm{l})$

- Nivel optim: $30-100 \mathrm{ng} / \mathrm{ml}(75-250 \mathrm{nmol} / \mathrm{l})$

- Exces $>100 \mathrm{ng} / \mathrm{ml}(>250 \mathrm{nmol} / \mathrm{l})$

- Toxicitate $>150 \mathrm{ng} / \mathrm{ml}(>325 \mathrm{nmol} / \mathrm{l})(16)$.

Efectele şi implicațiile vitaminei $D$ în creşterea şi dezvoltarea organismului sunt în continuu studiate. Manifestările clasice ale deficienței vitaminei D, întâlnite la copil şi adult, sunt rahitismul şi osteomalacia; ambele se caracterizează prin mineralizarea deficitară a matricei osoase şi, de cele mai multe ori, sunt consecința combinației dintre expunerea inadecvată la lumina soarelui şi scăderea aportului de vitamina D în dietă. Dar rahitismul are efecte extra musculo-scheletale, fiind raportate cazuri de cardiomiopatie asociate cu nivele scăzute de $25(\mathrm{OH}) \mathrm{D}$ şi rahitism. În plus, deşi rahitismul clasic afectează în cea mai mare parte copiii cu vârsta cuprinsă între 6 şi 24 luni şi până la 5 ani, sunt întâlnite cazuri de rahitism cu convulsii hipocalcemice şi la adolescenți (17).

Cercetările sugerează că vitamina D ar putea juca un rol în prevenirea şi tratarea mai multor afecțiuni, inclusiv obezitatea, diabetul zaharat, hipertensiunea arterială, bolile cardiovasculare, alergiile, bolile infecțioase şi scleroza multiplă, dar şi în imunitate şi dezvoltarea creierului şi a sistemului nervos în general şi se pare că influenţează expresia genelor implicate în dezvoltarea cancerului.

Obezitatea este o boală cronică netransmisibilă, cu etiologie multifactorială, prevalența fiind în continuă creştere la nivel mondial, astfel încât, în prezent, în special la vârsta pediatrică, este considerată una dintre cele mai grave probleme de sănătate publică ale secolului XXI. Obezitatea şi deficitul de vitamina $D$ se numără printre cei mai importanți factori de risc modificabili în rândul bolilor cronice. $\mathrm{Cu}$ toate acestea, rămâne controversat dacă asocierea acestora este constantă sau incidentală (18).

Având în vedere procesele fiziologice întâlnite la pubertate şi adolescență, se pare că suplimentarea cu vitamina $\mathrm{D}$ contribuie la scăderea în greutate şi, de asemenea, la prevenția demineralizării osoase la copiii obezi cu deficit de vitamină D (19).

Studiile epidemiologice şi observaționale sunt focusate pe studierea relației dintre statusul vitaminei D şi sindromul metabolic, markerii de adipozitate şi rezistența la insulină la copiii şi adulții obezi. Rămâne în continuare de stabilit momentul în care intervine vitamina $\mathrm{D}$ pentru a dezvolta o strategie de sănătate publică a bolilor cardio-metabolice prin prevenția deficitului de vitamină D. De asemenea, cunoscând legătura dintre nivelul vitaminei D, ho- meostazia metabolismului fosfo-calcic şi integritatea sistemului osteo-articular, asigurarea unui nivel optim de vitamină $\mathrm{D}$, dublată de un stil de viață sănătos, poate contribui la prevenirea rezistenței la insulină şi a diabetului zaharat $(20,21)$.

Datele actuale arată că $25(\mathrm{OH}) \mathrm{D}$ este un puternic imunomodulator implicat în reducerea inflamației sistemice. Nivelul plasmatic al vitaminei $\mathrm{D}$ este invers proporțional cu o serie de biomarkeri proinflamatori asociați cu dezvoltarea insulinorezistenței. Datele din literatură au arătat că prevalența deficitului de vitamină $\mathrm{D}$ ar fi mai ridicată la subiecții obezi, dar în continuare rămâne în focus întrebarea dacă deficitul de vitamină D este cauză sau consecință a obezității.

S-a observat că hipovitaminoza D se asociază cu hiperglicemia, hiperinsulinemia, scăderea funcției celulelor beta-pancreatice, precum şi cu insulinorezistența, deci, cu un risc crescut de diabet zaharat de tip 2. Cu toate acestea, rezultatele obținute arată necesitatea continuării cercetărilor în vederea stabilirii nivelului optim de $25(\mathrm{OH}) \mathrm{D}$ pentru prevenția diabetului de tip $2(22,23)$.

Factorii de risc pentru boala cardiovasculară $(\mathrm{BCV})$ sunt asociați cu concentrații serice scăzute de $25(\mathrm{OH})$ D în studiile observaționale (24). Efectele posibile ale vitaminei $\mathrm{D}$ asupra tensiunii arteriale sunt explicate prin implicarea în disfuncția endotelială şi modularea sistemului renină-angiotensină. Astfel, la pacienții hipertensivi cu renină plasmatică scăzută, s-a observat că tratamentul cu vitamina $\mathrm{D}$ a crescut activitatea reninei plasmatice (25).

Dovezile epidemiologice din ultimul deceniu sugerează implicarea vitaminei D şi în patogeneza alergiilor alimentare. S-a observat că riscul de alergie alimentară s-a asociat cu gradul de expunere la soare, latitudine, sezonul în care se naşte copilul şi nivelul seric al vitaminei $\mathrm{D}$. O înțelegere a rolului pe care îl joacă vitamina $\mathrm{D}$ în sistemul imunitar la nivel celular şi genetic, precum şi interacțiunea dintre microbiom şi vitamina D vor oferi o perspectivă asupra impactului acesteia în alergiile alimentare (26).

Vitaminele şi metaboliții lor au o funcție de control importantă în menţinerea imunităţii prin influențarea atât a răspunsurilor imune înnăscute cât şi a celor dobândite. În ultimele decenii, modelele animale au contribuit în mod semnificativ la înțelegerea mecanismelor fiziopatologice ale bolilor alergice, cum ar fi astmul, anafilaxia sau alergia alimentară (27). Dovezile consistente din studiile pe animale privind impactul multiplu al vitaminelor D şi A asupra sistemului imun atrag atenția asupra ro- 
lului acestora în controlul alergiilor, dar sunt necesare studii randomizate controlate la om. Aceste constatări subliniază importanța determinării statusului vitaminic la pacienții alergici şi în special al vitaminei D (28). În prezent există numeroase studii cu preparate de vitamina $\mathrm{D}$, care încearcă să răspundă la întrebarea dacă suplimentarea este implicată în reducerea prevalenței infecțiilor tractului respirator, inclusiv la grupele de risc (sugarii, vârstnicii, imunodeficiențele, astmul bronşic, boala pulmonară obstructivă cronică, dializa şi pacienții cu HIV). Sunt necesare cercetări suplimentare pentru a elucida mecanismele prin care vitamina $D$ intervine în prevenirea sau reducerea statusului infecțios $(29,30)$.

Deficitul de vitamina D a fost asociat cu un număr mare de patologii, incluzând şi cancerul de piele, tulburările cutanate autoimune, fotodermatoza, dermatita atopică şi psoriazisul, dar sunt necesare mai multe dovezi pentru a înțelege relațiile dintre vitamina D şi patologia cutanată (31).

\section{CONCLUZII}

Prevalența deficitului şi a insuficienței vitaminei D este ridicată şi datele actuale sugerează o creştere în viitor. Deficitul de vitamina D este în ultimii ani, o preocupare din ce în ce mai răspândită în materie de sănătate publică, având în vedere implicațiile cu răsunet pe termen lung. „Participarea" deficitului de vitamina $\mathrm{D}$ este binecunoscută în rahitism, întârzierea creşterii, hipocalcemie, iar în prezent se discută tot mai mult de asocierea cu bolile cronice non-musculo-scheletice, reprezentate de bolile cardiovasculare, atopia, obezitatea, diabetul zaharat, bolile autoimune, infecții, neoplazii. Pentru a realiza o profilaxie corectă, adecvată este necesar să ținem cont de etapele de creştere şi dezvoltare, începând cu viața intrauterină, fiecare având particularități şi nevoi diferite, precum şi de factorii familiali, de mediu şi stilul de viață. Factorii de risc pentru deficiența de vitamina $\mathrm{D}$ sunt numeroşi, unii dintre ei fiind modificabili. Cunoscând implicațiile multiple ale vitaminei D în organism, sunt tot mai multe dovezi care sugerează necesitatea evaluărilor de screening, suplimentarea cu produse medicamentoase în anumite situaţii şi tratament orientat. 